\title{
Determinação do Valor Energético de Alimentos para Ruminantes pelo Sistema de Equações
}

\author{
Vicente Ribeiro Rocha Júnior ${ }^{1}$, Sebastião de Campos Valadares Filho ${ }^{2}$, Álan Maia Borges ${ }^{3}$, \\ Karla Alves Magalhães ${ }^{2}$, Camila Celeste Brandão Ferreiraa ${ }^{4}$, Rilene Ferreira Diniz Valadares ${ }^{2}$, \\ Mário Fonseca Paulino ${ }^{2}$
}

\begin{abstract}
RESUMO - Neste trabalho objetivou-se avaliar o sistema de equações na determinação dos valores de NDT de seis alimentos volumosos (silagem de milho, cana-de-açúcar com $1 \%$ de uréia, feno de capim-coastcross 1 , feno de capim-coastcross 2 , silagem présecada de capim-tifton e capim-elefante) e de 12 alimentos concentrados (fubá de milho, grão de sorgo moído, gérmen de milho, farelo de trigo, farelo de arroz integral, farelo de babaçu, farelo de soja, farelo de algodão, caroço de algodão, glúten de milho, farelo de glúten de milho e casca de soja), utilizando-se ovinos como animais experimentais. Volumosos e concentrados foram combinados em dois níveis, com quatro repetições para cada nível, a partir de um delineamento experimental inteiramente casualizado. Os mesmos animais foram utilizados nos dois níveis do ingrediente concentrado, em dois períodos consecutivos. As dietas referentes aos dois níveis do alimento concentrado foram isonitrogenadas. A silagem de milho, a cana-de-açúcar com $1 \%$ de uréia, o feno de capim-coastcross 1 , o feno de capimcoastcross 2, a silagem pré-secada de capim-tifton e o capim-elefante apresentaram os seguintes valores de NDT, respectivamente: 59,56; 60,$57 ; 48,59 ; 50,24 ; 60,49 ;$ e 49,59\%. Já para os concentrados, constataram-se os seguintes valores de NDT: fubá de milho (93,75\%), grão de sorgo moído (82,82\%), gérmen de milho (85,30\%), farelo de trigo (74,28\%), farelo de arroz integral (80,65\%), farelo de babaçu $(49,38 \%)$, farelo de soja $(83,24 \%)$, farelo de algodão $(67,75 \%)$, caroço de algodão $(88,07 \%)$, glúten de milho $(85,34 \%)$, farelo de glúten de milho $(75,61 \%)$ e casca de soja $(68,95 \%)$. O sistema de equações foi eficiente na determinação do valor energético dos alimentos devido à alta correlação obtida entre esses valores e as digestibilidades da matéria seca e matéria orgânica do conjunto de alimentos avaliados.
\end{abstract}

Palavras-chave: alimentos, consumo, digestibilidade, nutrientes digestíveis

\section{Determination of Energy Value of Feed for Ruminants by Equations System}

\begin{abstract}
The objective was to evaluate the equations system for determination of the TDN of six forages (corn silage, sugar cane with $1 \%$ urea, coastcross grass hay 1 , coastcross grass hay 2, tifton grass haylage and elephant grass) and 12 concentrate feeds (corn grain ground, sorghum grain ground, corn germ, wheat bran, rice bran, babaçu meal, soybean meal, cotton meal, cotton seed, corn gluten, corn gluten meal and soybean hull) were determined using sheep as experimental animals. Forages and concentrates feed were combined in two different levels, following a completely randomized design with four repetitions for each level. The same animals were utilized to the two concentrate levels, in two consecutive periods. The diets refering to the two concentrate levels were isonitrogenous. The corn silage, sugar cane with $1 \%$ urea, coastcross grass hay 1, coastcross grass hay 2, tifton grass haylage and elephant grass presented, respectively, the following TDN values: 59.56, 60.57, 48.59, 50.24, 60.49 and $49.59 \%$. The concentrate feeds presented the following TDN values: corn grain ground (93.75\%), sorghum grain ground $(82.82 \%)$, corn germ $(85.30 \%)$, wheat bran $(74.28 \%)$, rice bran $(80.65 \%)$, babaçu meal (49.38\%), soybean meal (83.24\%), cotton meal $(67.75 \%)$, cotton seed $(88.07 \%)$, corn gluten (85.34\%), corn gluten meal $(75.61 \%)$ and soybean hull $(68.95 \%)$. The equations system was efficient in determination of the energy value of feed, because the high correlation between those values and the digestibilities of dry matter and organic matter of all feeds evaluated.
\end{abstract}

Key Words: digestibility, digestible nutrients, feed, intake

\section{Introdução}

A digestibilidade do alimento é, basicamente, sua capacidade de permitir que o animal utilize, em maior ou menor escala, seus nutrientes. Essa capacidade é expressa pelo coeficiente de digestibilidade do nutriente, em que devem ser respeitadas as diferenças entre ruminantes e monogástricos (Coelho da Silva \& Leão, 1979). A digestão é um processo de conversão de macromoléculas do alimento para compostos simples que podem ser absorvidos em alguns locais do trato gastrintestinal. Assim, medidas de digestibilidade têm contribuído significativamente para o desenvolvimento de sistemas que descrevem o valor nutritivo dos

\footnotetext{
1 Universidade Estadual de Montes Claros - Av. Rui Braga s/n, Campus Universitário Darcy Ribeiro - Prédio da Reitoria, Vila Mauricéia, Montes Claros (MG). E.mail: rochajuniorvr@hotmail.com

2 Universidade Federal de Viçosa - Av. PH Holfs, s/ n , Campus Universitário - CEP: 36570-000; Viçosa, MG.

3 Universidade Federal de MInas Gerais - Caixa Postal 567; CEP: 30123-970; Belo Horizonte, MG.

4 Zootecnista pela Universidade Federal de Viçosa - Viçosa, MG.
} 
alimentos (Van Soest, 1994).

A determinação do valor nutricional dos alimentos, com base somente nas análises químicas, tem pouca validade. Os métodos in vitro podem ser úteis para os melhoristas de plantas em uma seleção inicial, mas os dados obtidos não são adequados para sua utilização na formulação de rações. Somente valores obtidos com animais têm sido usados no balanceamento das dietas (Coelho da Silva \& Leão, 1979). Portanto, os atributos biológicos de um alimento são muito mais significativos na predição do desempenho animal; todavia, são mais difíceis de serem determinados acuradamente, devido à interação da composição química do alimento com as capacidades metabólicas e digestivas do animal (Preston, 1999).

Um dos problemas ligados à determinação da digestibilidade é o efeito associativo ou interação entre diferentes componentes de uma ração. É conhecido o fato de que a incorporação de grãos numa ração reduz a digestibilidade da fibra. Kromann (1973), citado por Rodriguez (1978), afirmou que a digestibilidade total da dieta não é necessariamente a soma das digestibilidades dos ingredientes e sugeriu a utilização de equações simultâneas para calcular a energia digestível dos ingredientes. Segundo Teixeira (1997), a técnica de determinação da digestibilidade por sistema de equações pode ser utilizada quando o alimento a ser avaliado não preenche o volume fisiológico do trato gastrintestinal. Especialmente para ruminantes, esta técnica se aplica para avaliação de alimentos concentrados. Trabalhando com duas ou mais rações, pode-se amenizar os erros decorrentes do efeito associativo entre os ingredientes.

Cappelle (2000), visando fornecer dados médios da composição dos alimentos brasileiros, verificou a inexistência de resultados de análises de alguns parâmetros para os respectivos alimentos dentro da bibliografia consultada. De acordo com este autor, em termos de composição de alimentos, observa-se que há carência de informações sobre o valor energético dos mesmos. Neste contexto, é importante considerar que os valores de energia disponível dos alimentos obtidos por meio de equações devem ser comparados com os valores reais, para que se possa ter confiabilidade nos modelos de predição. Isto reforça a necessidade dos estudos de digestão a fim de determinar o valor energético dos alimentos.

Desta forma, objetivou-se neste estudo avaliar o sistema de equações como metodologia na determinação da digestibilidade dos alimentos.

\section{Material e Métodos}

O trabalho foi conduzido no Laboratório de Animais do Departamento de Zootecnia da Universidade Federal de Viçosa, entre os meses de julho e setembro de 2000. O município de Viçosa situa-se na Zona da Mata Mineira do Estado de Minas Gerais.

Foram determinados os valores de nutrientes digestíveis totais (NDT) de seis alimentos volumosos (silagem de milho, cana-de-açúcar com 1\% de uréia, feno de capim-coastcross 1, feno de capimcoastcross 2 , silagem pré-secada de capim-tifton e capim-elefante) e de 12 alimentos concentrados (fubá de milho, grão de sorgo moído, gérmen de milho, farelo de trigo, farelo de arroz integral, farelo de babaçu, farelo de soja, farelo de algodão, caroço de algodão, glúten de milho, farelo de glúten de milho e casca de soja) com 24 ovinos machos, castrados, sem raça definida, de aproximadamente $45 \mathrm{~kg}$ de peso.

Volumosos e concentrados foram combinados em dois níveis distintos, com quatro repetições para cada nível, a partir de um delineamento experimental inteiramente casualizado. Os mesmos quatro animais foram utilizados nos dois níveis do ingrediente concentrado ou volumoso, em dois períodos consecutivos, com exceção do farelo de soja e do farelo de algodão, que foram associados, respectivamente, à silagem de milho e ao capim-elefante durante o mesmo período experimental. Assim, os alimentos foram combinados da seguinte maneira: feno de capim-coastcross 1 (com 10 e 30\% de fubá de milho; com 10 e $30 \%$ de grão de sorgo moído; com 10 e $30 \%$ de farelo de trigo; com 5 e $17 \%$ de caroço de algodão), feno de capim-coastcross 2 (com 5 e $15 \%$ de glúten de milho; com 10 e $30 \%$ de casca de soja; com 10 e $20 \%$ de farelo de arroz integral; com 10 e $30 \%$ de farelo de babaçu; com 15 e $30 \%$ de gérmen de milho; com 10 e $25 \%$ de farelo de glúten de milho), silagem de milho (com 15 e $30 \%$ de farelo de soja) e capim-elefante (com 25 e $35 \%$ de farelo de algodão). Apenas a cana-de-açúcar com $1 \%$ de uréia e a silagem pré-secada de capim-tifton foram avaliadas isoladamente, devido aos níveis mais elevados de proteína desses volumosos. O feno de capimcoastcross 2 também foi avaliado desta forma no último período experimental.

O experimento foi desenvolvido em cinco períodos, tendo sido utilizados 24 carneiros nos quatro primeiros, e 12 animais no último período. Em cada período, os alimentos ou níveis foram assim dispostos: 
Período 1- 10\% fubá de milho, $10 \%$ grão de sorgo moído, $10 \%$ farelo de trigo, $5 \%$ caroço de algodão, $15 \%$ farelo de soja, $30 \%$ farelo de soja; período 2$30 \%$ fubá de milho, $30 \%$ grão de sorgo moído, $30 \%$ farelo de trigo, $17 \%$ caroço de algodão, cana-deaçúcar com $1 \%$ de uréia, silagem pré-secada de capim-tifton; período 3-10\% farelo de arroz integral, $10 \%$ farelo de babaçu, $15 \%$ gérmen de milho, $5 \%$ glúten de milho, $10 \%$ farelo de glúten de milho, $10 \%$ casca de soja; período 4- 20\% farelo de arroz integral, $30 \%$ farelo de babaçu, $30 \%$ gérmen de milho, $15 \%$ glúten de milho, $25 \%$ farelo de glúten de milho, $30 \%$ casca de soja; perído 5- 25\% farelo de algodão, $35 \%$ farelo de algodão, feno de capim-coastcross 2.

Os animais foram pesados no início e final de cada período experimental, e a vermifugação dos mesmos foi realizada antes de se iniciar o experimento, e entre o segundo e terceiro período. Após a primeira pesagem, efetuou-se a distribuição dos animais do mais pesado ao mais leve, de modo que para cada alimento concentrado foram utilizados animais com pesos médios semelhantes. Os animais ficaram alojados em gaiolas, providas de bebedouro e cochos separados para o fornecimento da ração e do suplemento mineral. Na coleta de fezes, foram usadas sacolas especiais de napa, adaptadas aos animais.

Os coeficientes de digestibilidade da matéria seca (DMS), da matéria orgânica (DMO), da proteína bruta (DPB), do extrato etéreo (DEE), da fibra em detergente neutro (DFDN) e dos carboidratos não fibrosos (DCNF) de cada alimento foram determinados pelo sistema de equações, conforme o seguinte exemplo: 0,90DMS Feno + 0,10DMS Milho = DMS obtida $(1)$ 0,70DMS Feno + 0,30DMS Milho = DMS obtida(2).

Um ensaio preliminar foi conduzido com três ingredientes concentrados (fubá de milho, grão de sorgo moído e farelo de trigo), sendo que cada um deles foi combinado a um mesmo feno (feno de capim-coastcross 1), nas mesmas proporções descritas acima, para verificar se havia interferência dos alimentos concentrados sobre a digestibilidade do feno, neste caso, todas as dietas tinham os mesmos teores de PB. Os resultados indicaram que tal interferência não foi importante, visto que a digestibilidade da matéria seca do feno de capimcoastcross 1 foi semelhante nas diferentes combinações, com valores de 43,39\% a partir das rações com fubá de milho, 43,75\% para as dietas à base de grão de sorgo moído e $41,71 \%$ com o farelo de trigo.

Para previnir o efeito do teor de proteína bruta (PB) da ração sobre a digestibilidade, as dietas referentes aos dois níveis do alimento concentrado foram isonitrogenadas; tendo sido a uréia utilizada para essa correção.

O ensaio de digestibilidade foi conduzido pelo método de coleta total de fezes, e cada período teve duração de 15 dias, com 10 dias de adaptação e cinco dias de coleta. Apenas o primeiro período teve duração de 20 dias, devido à necessidade de adaptação dos animais às gaiolas. Os alimentos foram fornecidos à vontade, permitindo-se 10 a $15 \%$ de sobras. As sobras eram recolhidas e pesadas diariamente às 6 horas e os alimentos fornecidos em seguida. Durante o período de coleta, as amostras das sobras de alimento foram compostas por animal, acondicionadas em sacos plásticos armazenados em freezer para análises posteriores.

As fezes foram coletadas diariamente às 7 e 17 horas, registrando-se a quantidade excretada por animal. Após a homogenização do material, foram retiradas 5 a $10 \%$ da quantidade produzida para confecção de uma amostra composta por animal. As amostras foram colocadas em sacos plásticos e armazenadas em freezer. As amostras de alimentos, sobras e fezes foram pré-secas em estufa de ventilação forçada a $65^{\circ} \mathrm{C}$, por 72 horas, moídas em moinho de faca tipo "Willey", em peneira de $1 \mathrm{~mm}$ e encaminhadas para análises laboratoriais.

A composição química e bromatológica dos alimentos, das sobras e das fezes dos animais foi determinada. As análises de matéria seca (MS), compostos nitrogenados $(\mathrm{N})$, lignina, extrato etéreo (EE), matéria orgânica (MO) e cinzas foram realizadas conforme procedimentos descritos pela AOAC (1990). A fibra em detergente neutro (FDN) e fibra em detergente ácido (FDA), com as devidas correções para a presença de amido, foram determinadas seguindo as recomendações de Van Soest et al. (1991). Os teores de compostos nitrogenados insolúveis em detergente neutro (NIDN) e em detergente ácido (NIDA) foram estimados nos resíduos obtidos após extração das amostras nos detergentes neutro e ácido, respectivamente (Van Soest et al., 1991), por intermédio do procedimento de Kjeldahl (AOAC, 1990), sendo a FDN dos alimentos corrigida para os níveis de cinzas e proteínas.

Os carboidratos totais foram calculados segundo metodologia descrita por Sniffen et al. (1992), sendo que $\mathrm{CHOT}=100-(\% \mathrm{~PB}+\% \mathrm{EE}+\%$ Cinzas $)$ e os carboidratos não fibrosos (CNF) foram obtidos subtraindo-se dos CHOT a fração FDN. O NDT dos alimentos foi calculado a partir da seguinte fórmula: $\mathrm{NDT}=\mathrm{PBD}+\mathrm{CNFD}+\mathrm{FDNpD}+2,25 * \mathrm{EED}(\mathrm{NRC}$, 
2001), onde PBD = proteína bruta digestível, CNFD = carboidratos não fibrosos digestíveis, FDNpD = fibra em detergente neutro corrigida para proteína digestível, e EED = extrato etéreo digestível.

Os resultados de DMS, DMO e NDT dos alimentos foram submetidos à análise de regressão polinomial, sendo que para este procedimento, os alimentos foram agrupados em volumosos, concentrados e conjunto de alimentos (volumosos + concentrados), considerando-se nível de significância de 5\%.

\section{Resultados e Discussão}

Na Tabela 1, é apresentada a composição química dos alimentos estudados e na Tabela 2, a composição das dietas experimentais quanto aos teores de MS, MO, PB, FDNp, EE, CNF e CHOT.

Como pode ser visto na Tabela 2, os teores de PB das dietas foram similares entre os dois níveis de concentrado, com exceção das dietas compostas por casca de soja e feno de capim-coastcross. Todas as

Tabela 1 - Porcentagem de matéria orgânica (MO), proteína bruta (PB), extrato etéreo (EE), carboidratos não fibrosos (CNF), fibra em detergente neutro (FDN), fibra em detergente neutro corrigida para cinzas e proteínas (FDNcp), fibra em detergente ácido (FDA), lignina e compostos nitrogenados insolúveis em detergentes neutro (NIDN) e ácido (NIDA) dos ingredientes

Table 1 - Percentage of organic matter (OM), crude protein (CP), ether extract (EE), nonfiber carbohydrates (NFC), neutral detergent fiber (NDF), neutral detergent fiber corrected for ash and protein (NDFap), acid detergent fiber (ADF), lignin, insoluble in neutral detergent (NDIN) and acid detergent (ADIN) nitrogenous compounds of the ingredients

\begin{tabular}{|c|c|c|c|c|c|c|c|c|c|c|}
\hline $\begin{array}{l}\text { Alimentos } \\
\text { Feeds }\end{array}$ & $\begin{array}{l}\mathrm{MO}^{1} \\
\mathrm{OM}^{1}\end{array}$ & $\begin{array}{l}\mathrm{PB}^{1} \\
C P^{1} \\
\end{array}$ & $\begin{array}{l}\mathrm{EE}^{1} \\
E E^{1} \\
\end{array}$ & $\begin{array}{l}\mathrm{CNF}^{1} \\
N F C^{l} \\
\end{array}$ & $\begin{array}{l}\mathrm{FDN}^{1} \\
N D F^{l}\end{array}$ & $\begin{array}{l}\text { FDNcp } 1 \\
\text { NDFap }\end{array}$ & $\begin{array}{l}\mathrm{FDA}^{1} \\
A D F^{1}\end{array}$ & $\begin{array}{l}\text { Lignina }^{1} \\
\text { Lignin }^{1} \\
\end{array}$ & $\begin{array}{l}\mathrm{NIDN}^{2} \\
\text { NDIN }^{2} \\
\end{array}$ & $\begin{array}{l}\mathrm{NIDA}^{2} \\
A D I N^{2} \\
\end{array}$ \\
\hline $\begin{array}{l}\text { Fubá de milho } \\
\text { Corn grain ground }\end{array}$ & 98,94 & 7,79 & 4,78 & 75,10 & 11,61 & 10,65 & 3,18 & 0,64 & 9,09 & 2,73 \\
\hline $\begin{array}{l}\text { Sorgo grão } \\
\text { Sorghum grain ground }\end{array}$ & 98,71 & 10,45 & 2,28 & 70,52 & 14,58 & 11,47 & 7,45 & 1,57 & 26,79 & 23,66 \\
\hline $\begin{array}{l}\text { Farelo de trigo } \\
\text { Wheat bran }\end{array}$ & 94,00 & 17,54 & 3,95 & 35,20 & 38,53 & 34,33 & 13,47 & 2,88 & 21,35 & 4,27 \\
\hline $\begin{array}{l}\text { Farelo de arroz } \\
\text { Rice bran }\end{array}$ & 89,61 & 13,74 & 13,10 & 39,58 & 24,05 & 21,08 & 8,25 & 0,95 & 19,51 & 10,92 \\
\hline $\begin{array}{l}\text { Gérmen de milho } \\
\text { Corn germ }\end{array}$ & 97,54 & 9,31 & 7,23 & 49,52 & 32,39 & 28,30 & 9,02 & 2,01 & 41,83 & 7,92 \\
\hline $\begin{array}{l}\text { Farelo de babaçu } \\
\text { Babaçu meal }\end{array}$ & 95,45 & 16,48 & 1,14 & 1,83 & 78,68 & 68,88 & 53,78 & 3,89 & 53,05 & 13,54 \\
\hline $\begin{array}{l}\text { Farelo de soja } \\
\text { Soybean meal }\end{array}$ & 92,26 & 50,15 & 2,21 & 29,40 & 12,40 & 11,18 & 8,50 & 1,68 & 2,32 & 1,01 \\
\hline $\begin{array}{l}\text { Farelo de algodão } \\
\text { Cottonseed meal }\end{array}$ & 94,81 & 32,07 & 0,98 & 19,21 & 43,32 & 40,76 & 33,59 & 3,31 & 6,97 & 5,78 \\
\hline $\begin{array}{l}\text { Caroço de algodão } \\
\text { Cottonseed high lint }\end{array}$ & 96,61 & 23,56 & 20,31 & 11,18 & 41,95 & 40,16 & 30,88 & 3,56 & 6,68 & 4,58 \\
\hline $\begin{array}{l}\text { Glúten de milho } \\
\text { Corn gluten }\end{array}$ & 92,53 & 65,04 & 1,74 & 19,98 & 6,54 & 2,72 & 3,51 & 1,78 & 5,71 & 3,42 \\
\hline $\begin{array}{l}\text { F. de glúten milho } \\
\text { Corn gluten meal }\end{array}$ & 93,66 & 23,22 & 3,88 & 30,72 & 37,70 & 33,29 & 10,85 & 1,48 & 14,38 & 3,17 \\
\hline $\begin{array}{l}\text { Casca de soja } \\
\text { Soybean hull }\end{array}$ & 92,32 & 11,94 & 3,04 & 17,65 & 64,52 & 59,15 & 50,83 & 3,14 & 37,55 & 9,01 \\
\hline $\begin{array}{l}\text { Silagem de milho } \\
\text { Corn silage }\end{array}$ & 94,52 & 7,25 & 2,00 & 38,40 & 49,60 & 47,90 & 28,06 & 3,49 & 14,05 & 7,17 \\
\hline $\begin{array}{l}\text { Capim-elefante } \\
\text { Elephantgrass }\end{array}$ & 92,02 & 7,66 & 2,25 & 7,34 & 76,57 & 73,61 & 51,39 & 7,54 & 20,72 & 8,76 \\
\hline $\begin{array}{l}\text { Cana-de-açúcar ( } 1 \% \text { uréia) } \\
\text { Sugar cane }(1 \% \text { urea) }\end{array}$ & 97,49 & 11,2 & 0,93 & 45,83 & 40,00 & 39,05 & 21,52 & 3,52 & 5,66 & 2,76 \\
\hline $\begin{array}{l}\text { Silag. pré-seca Tifton } \\
\text { Tifton grass haylage }\end{array}$ & 92,00 & 16,73 & 2,31 & 8,76 & 67,06 & 59,94 & 33,05 & 4,22 & 32,71 & 8,85 \\
\hline $\begin{array}{l}\text { Feno coastcross } 1 \\
\text { Coastcross grass hay } 1\end{array}$ & 94,67 & 5,65 & 1,50 & 3,77 & 86,59 & 81,57 & 45,06 & 6,23 & 52,00 & 15,35 \\
\hline $\begin{array}{l}\text { Feno coastcross } 2 \\
\text { Coastcross grass hay } 2\end{array}$ & 92,22 & 11,05 & 1,81 & 5,82 & 76,37 & 69,71 & 39,65 & 4,49 & 44,71 & 6,80 \\
\hline
\end{tabular}

${ }^{1}$ Expresso na base da matéria seca; ${ }^{2}$ Em porcentagem dos compostos nitrogenados totais.

${ }^{1}$ In dry matter basis; ${ }^{2}$ In percentage of overall nitrogenous compounds. 
Tabela 2 - Teores de matéria seca (MS), matéria orgânica (MO), proteína bruta (PB), extrato etéreo (EE), fibra em detergente neutro corrigida para proteína (FDNp), carboidratos totais (CHOT) e carboidratos não fibrosos (CNF) das dietas experimentais, expressos na base da MS

Table 2 - Percentage of dry (DM), organic matter (OM), crude protein (CP), ether extract (EE), neutral detergent fiber corrected for protein (NDFp), total carbohydrates (TCHO), nonfiber carbohydrates (NFC) of experimental diets, in dry matter basis

\begin{tabular}{|c|c|c|c|c|c|c|c|}
\hline $\begin{array}{l}\text { Tratamentos } \\
\text { Treatments }\end{array}$ & MS & $\mathrm{MO}$ & $\mathrm{PB}$ & $\mathrm{EE}$ & FDNp & CHOT & CNF \\
\hline Treatments & $D M$ & $O M$ & $C P$ & & & & \\
\hline $10 \%$ Fubá de milho (10\% Corn grain ground) ${ }^{1}$ & 89,70 & 94,02 & 8,93 & 1,76 & 75,97 & 86,44 & 10,47 \\
\hline $30 \%$ Fubá de milho (30\% Corn grain ground $)^{1}$ & 88,57 & 95,10 & 8,50 & 2,44 & 62,00 & 86,43 & 24,43 \\
\hline $10 \%$ Sorgo grão (10\% Sorghum grain ground $)^{1}$ & 89,66 & 94,05 & 8,86 & 1,56 & 76,45 & 86,46 & 10,01 \\
\hline $30 \%$ Sorgo grão (30\% Sorghum grain ground $)^{1}$ & 88,46 & 95,15 & 8,87 & 1,71 & 63,63 & 86,46 & 22,83 \\
\hline $10 \%$ F. de trigo $(10 \% \text { Wheat bran })^{1}$ & 86,09 & 93,81 & 8,91 & 1,73 & 78,89 & 85,60 & 6,71 \\
\hline $30 \%$ F. de trigo ( $30 \%$ Wheat bran $)^{1}$ & 88,90 & 94,48 & 8,84 & 2,21 & 71,39 & 84,00 & 12,61 \\
\hline $10 \% \mathrm{~F}$. de arroz $(10 \% \text { Rice bran })^{2}$ & 88,64 & 91,92 & 11,44 & 2,88 & 68,73 & 77,75 & 9,02 \\
\hline $20 \%$ F. de arroz $(20 \% \text { Rice bran })^{2}$ & 88,13 & 91,72 & 11,56 & 3,97 & 63,94 & 76,21 & 12,27 \\
\hline $15 \%$ Gérmen milho $(15 \% \text { Corn germ })^{2}$ & 89,03 & 93,01 & 10,79 & 2,62 & 67,28 & 79,61 & 12,33 \\
\hline $30 \%$ Gérmen milho $(30 \% \text { Corn germ })^{2}$ & 88,94 & 93,81 & 10,53 & 3,43 & 60,99 & 79,85 & 18,86 \\
\hline $10 \%$ F. de babaçu (10\% Babaçu meal $)^{2}$ & 89,39 & 92,14 & 12,68 & 1,73 & 73,48 & 78,86 & 5,38 \\
\hline $30 \%$ F. de babaçu (30\% Babaçu meal $)^{2}$ & 89,79 & 93,21 & 12,71 & 1,61 & 74,30 & 78,90 & 4,60 \\
\hline $15 \%$ F. de soja $(15 \% \text { Soybean meal })^{3}$ & 33,90 & 91,77 & 20,21 & 1,98 & 40,88 & 76,89 & 36,01 \\
\hline $30 \%$ F. de soja $(30 \% \text { Soybean meal })^{3}$ & 42,32 & 93,86 & 19,69 & 2,06 & 37,24 & 73,03 & 35,79 \\
\hline $25 \%$ F. algodão (25\% Cottonseed meal $)^{4}$ & 36,49 & 91,81 & 17,10 & 1,96 & 65,89 & 75,36 & 9,47 \\
\hline $35 \%$ F. algodão (35\% Cottonseed meal $)^{4}$ & 46,13 & 93,03 & 16,53 & 1,79 & 60,67 & 73,32 & 11,65 \\
\hline $5 \%$ Caroço algodão $(5 \% \text { Cottonseed })^{1}$ & 90,29 & 93,94 & 8,71 & 2,44 & 80,89 & 85,01 & 4,12 \\
\hline $17 \%$ Caroço algodão $(17 \% \text { Cottonseed })^{1}$ & 90,36 & 95,00 & 8,73 & 4,73 & 76,50 & 81,55 & 5,05 \\
\hline $5 \%$ Glúten milho $(5 \% \text { Corn gluten })^{2}$ & 90,39 & 92,53 & 13,93 & 1,48 & 78,03 & 82,54 & 4,51 \\
\hline $15 \%$ Glúten milho $(15 \% \text { Corn gluten })^{2}$ & 90,30 & 94,35 & 14,63 & 1,53 & 71,95 & 78,18 & 6,23 \\
\hline $10 \%$ F. Glúten milho (10\% Corn gluten meal $)^{2}$ & 88,92 & 92,03 & 13,10 & 2,01 & 69,62 & 77,84 & 8,22 \\
\hline $25 \%$ F. Glúten milho (25\% Corn gluten meal $)^{2}$ & 88,51 & 92,57 & 14,03 & 2,32 & 64,33 & 76,24 & 11,91 \\
\hline $10 \%$ Casca soja $(10 \% \text { Soybean hull })^{2}$ & 89,20 & 90,68 & 15,97 & 1,89 & 71,01 & 77,88 & 6,87 \\
\hline $30 \%$ Casca soja $(30 \% \text { Soybean hull })^{2}$ & 88,77 & 93,14 & 11,31 & 2,17 & 70,33 & 79,66 & 9,33 \\
\hline Cana-de-açúcar c/ 1\% Uréia (Sugar cane with $1 \%$ urea) & 26,34 & 97,49 & 11,20 & 0,93 & 39,53 & 85,36 & 45,83 \\
\hline Feno de coastcross 2 (Coastcross hay 2) & 89,13 & 92,22 & 11,05 & 1,81 & 73,56 & 79,38 & 5,82 \\
\hline Silagem pré-secada Tifton (Tifton haylage) & 47,18 & 92,00 & 16,73 & 2,31 & 64,20 & 72,96 & 8,76 \\
\hline
\end{tabular}

Combinados com: ${ }^{1}$ Feno de coastcross $1 ;{ }^{2}$ Feno de coastcross $2 ;{ }^{3}$ Silagem de milho; ${ }^{4}$ Capim-elefante.

Combined with: ${ }^{1}$ Coastcross hay $1 ;{ }^{2}$ Coastcross hay $2 ;{ }^{3}$ Corn silage; ${ }^{4}$ Elephantgrass.

dietas experimentais apresentaram teores de PB acima das necessidades mínimas $(7 \%)$ de ruminantes, sendo que as rações com farelo de soja e farelo de algodão apresentaram níveis elevados de proteína. Com relação aos teores de FDNp, pode ser verificado na Tabela 2 que os níveis de fibra foram altos em todas as dietas, apesar da cana-de-açúcar ter mostrado teor de FDN inferior ao valor médio de 55,87\% relatado por Valadares Filho et al. (2002). Quanto ao $\mathrm{EE}$, as dietas mostraram baixos teores, com exceção da dieta com $17 \%$ de caroço de algodão que teve $4,73 \%$ deste nutriente; todavia, acredita-se que este valor de EE não foi alto o suficiente para causar qualquer efeito depressor sobre a digestibilidade da fibra, além disso, os níveis de FDNp presentes neste tratamento foram elevados, o que favorece a digestão deste componente no rúmen.

A partir de sistemas de equações, as digestibilidades aparentes da MS, MO, PB, FDN, EE e CNF foram calculadas para cada alimento. $\mathrm{Na}$ Tabela 3 são apresentados os valores de NDT e os coeficientes de digestibilidade dos alimentos estudados. Os valores de NDT foram correspondentes às digestibilidades da MS e MO. A baixa digestibilidade da PB da casca de soja foi devida aos diferentes teores de proteína das rações, que influenciaram a digestibilidade da PB das dietas experimentais e, conseqüentemente, dos alimentos testados.

As médias com os respectivos valores de erropadrão do NDT, da DMS e da DMO, para alimentos volumosos, concentrados e conjunto de alimentos são apresentadas na Tabela 4. Foi constatada alta correlação entre DMS e DMO, DMS e NDT, DMO e NDT $\left(\mathrm{R}^{2}=0,98 ; 0,94 ;\right.$ e 0,94, respectivamente; $\left.\mathrm{P}<0,05\right)$, o que credibiliza os valores de NDT determinados neste experimento. Entretanto, recomenda-se caute- 
Tabela 3 - Valores de NDT e coeficientes de digestibilidade da MS (DMS), MO (DMO), PB (DPB), EE (DEE), FDN (DFDN) e CNF (DCNF) dos alimentos avaliados

Table 3 - TDN values and digestibility coefficients of DM (DMD), OM (OMD), CP (CPD), EE (EED), NDF (NDFD) and NFC (FNCD) of the feed

\begin{tabular}{|c|c|c|c|c|c|c|c|}
\hline $\begin{array}{l}\text { Alimentos } \\
\text { Feed }\end{array}$ & $\begin{array}{l}\text { NDT } \\
T D N\end{array}$ & $\begin{array}{l}\text { DMS } \\
D M D\end{array}$ & $\begin{array}{l}\mathrm{DMO} \\
O M D\end{array}$ & $\begin{array}{l}\mathrm{DPB} \\
C P D\end{array}$ & $\begin{array}{l}\text { DEE } \\
E E D\end{array}$ & $\begin{array}{l}\text { DFDN } \\
N D F D\end{array}$ & $\begin{array}{l}\mathrm{DCNF} \\
N F C D\end{array}$ \\
\hline Fubá de milho & 93,75 & 90,74 & 93,01 & 57,08 & 100,00 & 32,33 & 100,00 \\
\hline $\begin{array}{l}\text { Corn grain ground } \\
\text { Sorgo grão }\end{array}$ & 82,82 & 84,82 & 79,46 & 47,24 & 93,48 & 22,35 & 100,00 \\
\hline $\begin{array}{l}\text { Sorghum grain ground } \\
\text { Farelo de trigo } \\
\text { Wheat bran }\end{array}$ & 74,28 & 74,4 & 77,37 & 59,13 & 100,00 & 57,74 & 100,00 \\
\hline $\begin{array}{l}\text { Farelo de arroz } \\
\text { Rice bran }\end{array}$ & 80,65 & 80,54 & 85,75 & 53,65 & 100,00 & 20,04 & 100,00 \\
\hline $\begin{array}{l}\text { Gérmen de milho } \\
\text { Corn germ }\end{array}$ & 85,30 & 82,84 & 85,19 & 78,42 & 100,00 & 45,98 & 100,00 \\
\hline $\begin{array}{l}\text { Farelo de babaçu } \\
\text { Babaçu meal }\end{array}$ & 49,38 & 48,45 & 49,47 & 75,35 & 94,32 & 48,26 & 70,85 \\
\hline $\begin{array}{l}\text { Farelo de soja } \\
\text { Soybean meal }\end{array}$ & 83,24 & 88,67 & 83,02 & 91,27 & 100,00 & 27,69 & 100,00 \\
\hline $\begin{array}{l}\text { Farelo de algodão } \\
\text { Cottonseed meal }\end{array}$ & 67,75 & 73,62 & 73,32 & 70,97 & 49,45 & 60,58 & 100,00 \\
\hline $\begin{array}{l}\text { Caroço de algodão } \\
\text { Cottonseed }\end{array}$ & 88,07 & 72,32 & 72,43 & 68,71 & 100,00 & 44,37 & 74,82 \\
\hline $\begin{array}{l}\text { Glúten de milho } \\
\text { Corn gluten }\end{array}$ & 85,34 & 86,28 & 83,1 & 94,31 & 82,58 & 55,39 & 96,40 \\
\hline $\begin{array}{l}\text { F. de glúten milho } \\
\text { Corn gluten meal }\end{array}$ & 75,61 & 79,81 & 77,14 & 84,77 & 100,00 & 49,49 & 100,00 \\
\hline $\begin{array}{l}\text { Casca de soja } \\
\text { Soybean hull }\end{array}$ & 68,95 & 71,91 & 74,79 & 23,08 & 88,85 & 71,8 & 100,00 \\
\hline $\begin{array}{l}\text { Silagem de milho } \\
\text { Corn silage }\end{array}$ & 59,56 & 58,37 & 62,58 & 78,32 & 64,82 & 34,15 & 88,88 \\
\hline $\begin{array}{l}\text { Capim-elefante } \\
\text { Elephantgrass }\end{array}$ & 49,59 & 52,79 & 54,39 & 84,27 & 57,77 & 46,69 & 79,56 \\
\hline $\begin{array}{l}\text { Cana ( } 1 \% \text { uréia) } \\
\text { Sugar cane ( } 1 \% \text { urea) }\end{array}$ & 60,57 & 58,48 & 60,47 & 73,37 & 47,07 & 18,43 & 96,38 \\
\hline $\begin{array}{l}\text { Silag. Pré-seca Tifton } \\
\text { Tifton grass haylage }\end{array}$ & 60,49 & 66,49 & 65,63 & 71,94 & 70,87 & 67,78 & 47,31 \\
\hline $\begin{array}{l}\text { Feno coastcross } 1 \\
\text { Coastcross grass hay } 1\end{array}$ & 48,59 & 42,95 & 44,39 & 66,96 & 56,83 & 50,45 & 45,96 \\
\hline $\begin{array}{l}\text { Feno coastcross } 2 \\
\text { Coastcross grass hay } 2\end{array}$ & 50,24 & 53,25 & 55,25 & 68,35 & 64,90 & 55,45 & 23,84 \\
\hline
\end{tabular}

la na utilização desses valores, uma vez que se devem considerar as diferenças entre espécies de ruminantes e os diferentes níveis de alimentação.

As figuras 1, 2 e 3 mostram, respectivamente, as correlações entre DMS e DMO, DMS e NDT, DMO e NDT, para o conjunto de alimentos. Pelos elevados coeficiente de correlação encontrados e pela distribuição dos valores de NDT observados em relação à reta, certifica-se que a metodologia utilizada através do sistema de equações, com dois níveis de cada ingrediente, foi eficiente na determinação do valor energético dos alimentos.

Cappelle (2000), a partir de dados coletados nas teses publicadas pelo Departamento de Zootecnia da Universidade Federal de Viçosa, também encontrou a mesma tendência entre a DMS e DMO com os valores observados de NDT, tanto para rações concentradas, como para alimentos volumosos e dietas totais. $\mathrm{O}$ autor também detectou aumento dos teores de NDT, em função do aumento das digestibilidades da matéria seca e da matéria orgânica, e concluiu que, desde que respeitadas as características das populações, as equações estimadas poderão predizer, com certa precisão, os valores de NDT. 
Tabela 4 - Médias e respectivos erros-padrão para oNDT, DMS e DMO obtidos para alimentos volumosos, concentrados e conjunto de alimentos

Table 4 - Averages and standard errors for TDN, DMD, OMD obtained for forages, concentrates and overall feedstuffs

\begin{tabular}{|c|c|c|c|}
\hline $\begin{array}{l}\text { Alimentos } \\
\text { Feedstuffs }\end{array}$ & $\begin{array}{l}\text { NDT } \\
T D N \\
\end{array}$ & $\begin{array}{l}\text { DMS } \\
D M D\end{array}$ & $\begin{array}{l}\text { DMO } \\
O M D \\
\end{array}$ \\
\hline $\begin{array}{l}\text { Volumosos } \\
\text { Forages }\end{array}$ & $54,84 \pm 2,41$ & $55,39 \pm 3,20$ & $57,12 \pm 3,09$ \\
\hline $\begin{array}{l}\text { Concentrados } \\
\text { Concentrates }\end{array}$ & $77,93 \pm 3,42$ & $77,87 \pm 3,26$ & $77,84 \pm 3,10$ \\
\hline $\begin{array}{l}\text { Conjunto de } \\
\text { alimentos } \\
\text { All feedstuffs }\end{array}$ & $70,23 \pm 3,55$ & $70,37 \pm 3,49$ & $70,93 \pm 3,27$ \\
\hline
\end{tabular}

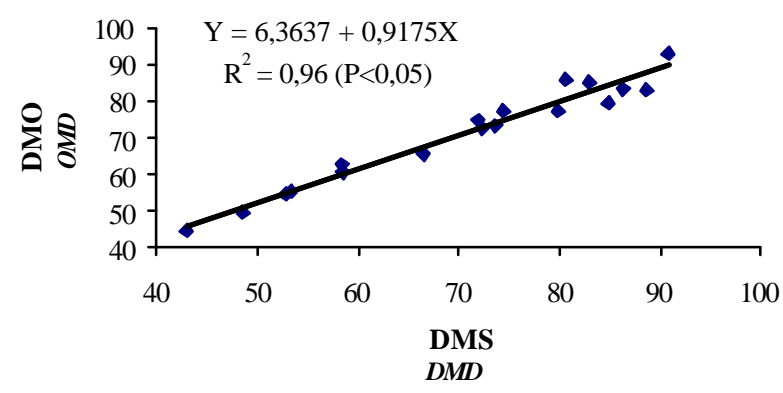

Figura 1 - Relação entre DMO e DMS para o conjunto de alimentos.

Figure 1 - Relation between OMD and DMD for overall feed.

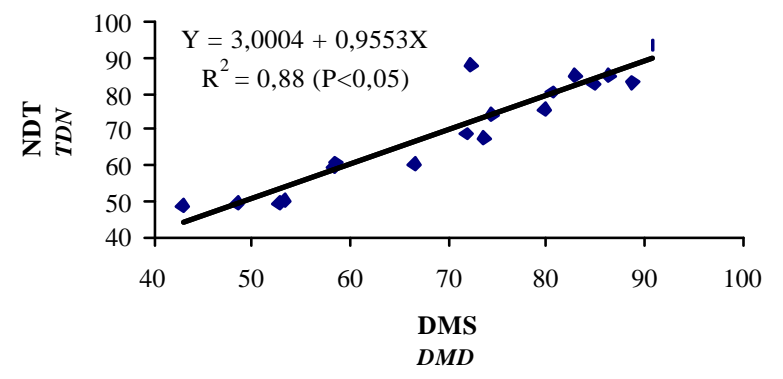

Figura 2 - Relação entre NDT e DMS para o conjunto de alimentos.

Figure 2 - Relation between TDN and DMD for overall feed.

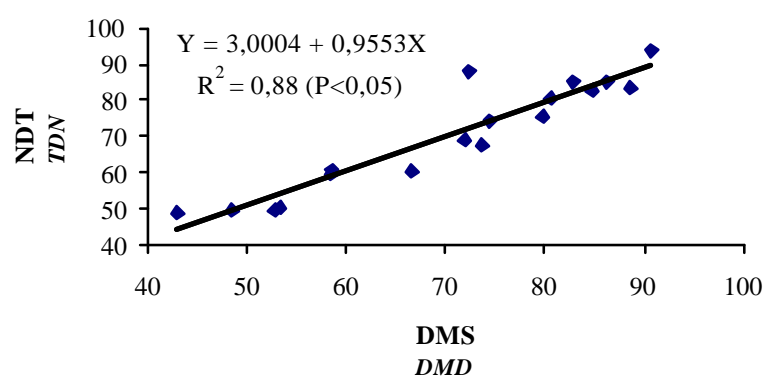

Figura 3 - Relação entre NDT e DMO para o conjunto de alimentos.

Figure 3 - Relation between TDN and OMD for overall feed.

\section{Conclusões}

O sistema de equações foi eficiente na determinação do valor energético dos alimentos, dada a correspondência entre os valores de NDT e as digestibilidades das matérias seca e orgânica dos alimentos avaliados.

\section{Literatura Citada}

\section{ASSOCIATION OF OFFICIAL ANALITICAL CHEMISTS -} AOAC. Official Methods of Analysis. 15.ed. Arlington, Virginia: 1990. 1117p.

CAPPELLE, E.R. Tabelas de composição dos alimentos, estimativa do valor energético e predição do consumo e do ganho de peso de bovinos. Viçosa, MG: Universidade Federal de Viçosa, 2000.369p. Tese (Doutorado em Zootecnia) - Universidade Federal de Viçosa, 2000.

COELHO DA SILVA, J.F.; LEÃO, M.I. Fundamentos de nutrição dos ruminantes. Piracicaba: Livroceres, 1979. 380p.

NATIONAL RESEARCH COUNCIL - NRC. Nutrients requirements of dairy cattle. 7.rev.ed. Washington, D.C.: National Academic of Sciences, 2001. 381p.

(Rever esta citação)PRESTON, R.L. Typical composition of feed for cattle and sheep. Feed Composition Guide, v.35, n.6, 1999. http: //www.home farm.com/, 1999.

RODRIGUEZ, N.M. Avaliação de Alimentos. In: SIMPÓSIO SOBRE EXIGÊNCIAS NUTRICIONAIS E AVALIAÇÃO DE ALIMENTOS PARA RUMINANTES NO BRASIL. Anais... Coronel Pacheco: Embrapa/CNPGL, 1978. p.72-93.

SNIFFEN, C.J.; CONNOR, J.D.; Van SOEST, P.J. et al. A net carbohydrate and protein system for evaluating cattle diets: II. Carbohydrate an protein availability. Journal Animal Science, v.70, n.11, p.3.562-3.577, 1992.

TEIXEIRA, J.C. Introdução aos métodos de determinação de digestibilidade em ruminantes. In: DIGESTIBILIDADE EM RUMINANTES, 1997, Lavras.Anais...Lavras: Universidade Federal de Lavras, 1997. p.7-27.

VALADARES FILHO, S.C.; ROCHA JR., V.R.; CAPPELLE, E.R. Tabelas brasileiras de composição de alimentos para bovinos. Viçosa, MG: Universidade Federal de Viçosa, 2002. 297p.

Van SOEST, P.J. Nutritional ecology of ruminant. 2.ed. Ithaca: Cornell University Press, 1994. 476p.

Van SOEST, P.J.; ROBERTSON, J.B.; LEWIS, B.A. Methods for dietary fiber, neutral detergent fiber, and nonstarch polyssacarides in relation to animal nutrition.Journal Animal Science, v.74, n.10, p.3583-3597, 1991. 